\title{
Patriarchal Masculinity in Recent Swahili-language Muslim Sermons
}

\author{
Felicitas Becker \\ History Faculty, University of Cambridge, UK \\ fmb26@cam.ac.uk
}

\begin{abstract}
This paper offers a close examination of statements on patriarchal masculinity from three widely traded sermon recordings produced in Zanzibar, Tanzania. It sets them in the context of Islamic reform, Muslim political discontent, and the consumption of sermon recordings in East Africa. Despite similar assertions on the need for men to protect and control women, in close reading the three preachers offer quite divergent characterisations of the patriarch's methods, obligations, and entitlements within the household. The sermons show that Islamic reform in Zanzibar cannot be reduced to political discontent, and that it hearkens back to longstanding regional history. They also suggest that the concept of patriarchy is more relevant to the understanding of asymmetrical gender relations than recent discussion of Western gender relations has allowed, and highlight the centrality of bearing and rearing children as a site for both assertion and failure of patriarchal control. Lastly, they indicate the failure of sermon preachers and listeners to coalesce into a coherent counterpublic.
\end{abstract}

\section{Keywords}

Islam - Islamic reform - women - gender and Islam - Islamic activism - preaching preachers

According to some recent statements, for instance by the World Bank, a 'crisis of masculinity' is in full swing in Africa (Barker et al. 2005). In this account men in Africa are a problem, especially when young: aggressively and promiscuously sexual and thus oblivious to HIV, prone to both spontaneous and organised violence, and disdainful of or unaccustomed to the virtues of ordered and 
productive work. To some extent this caricature is the flip side of the 'discovery' of African women as agents of developments; as the ones who, if educated, will bring up the next generation better, spend income on family welfare, responsibly pay back loans, and so on (Klugman et al. 2014). Clearly, both the positive and the negative claims made in this context are part of the politics of aid, international relations, and state-society relations within Africa. They are neither neutral nor purely descriptive.

If religion shows up in this sort of narrative, it is liable to do so in one of two ways: either religious social authority is construed as a restraining influence on the dangerous, exuberant masculinity of the young, and a support for the women having to work around it. See, for instance, the efforts of religious organisations in HIV/AIDS counselling in South Africa (Burchardt 2009). Conversely, religion can also fan the flames of masculine self-assertion. This is evident in the overwhelmingly young and male involvement on both Christian and Muslim sides in religious clashes in Nigeria, or the obvious gender dynamics in Boko Haram's recent atrocities in which men kill other men while abducting 'their' women (Mustafa 2014). Judging by news media coverage, Islam in particular appears to inspire an aggressive hypermasculinity.

Focusing on the way Swahili-speaking Muslim preachers discuss masculinity, this paper arrives at a different characterisation (even though, as will be seen, their views interact with donor policy speak). Listening to and observing the demeanour of such preachers, that is, speakers at Friday prayers at the mosque, or more often at mihadhara, religious educational gatherings that can take place at a variety of venues, traces out a more middle-aged, deeply patriarchal masculinity focused on order, not disruption, and particularly on the domestic sphere. Since the 199os these sermons have become increasingly common in the Swahili-speaking world, multiplied, passed on, and traded initially on audio cassette tapes and more recently on DVDs, which have the advantage of providing visual information on the speaker's habitus and the composition and responses of their audiences. The DVDs and tapes I have worked on were acquired during trips in 1999, 2000, 2004, 2004, 2005, 2010, 2012, and 2016 in a variety of locations in Kenya and Tanzania; some of the recorded sermons are likely to be somewhat older. Increasingly, the material from these DVDs is also available, often in better quality, via YouTube, and with the rise of WhatsApp listeners increasingly focus on favourite passages passed around within WhatsApp groups.

Altogether, I have acquired about 200 different sermons. The great majority was performed by a core group of speakers comprised of no more than ten names, all of them men, and most of them based in the long-standing Muslim congregations of coastal towns. Two of the three speakers discussed below, 
Nassor Bachu and Othman Maalim, belong to this core group. By contrast, the third speaker considered in detail is a recent, possibly passing fashion, and a fourth, fairly obscure one is drawn on because he particularly clearly addresses a core aspect of the patriarchal masculinity under examination. Questions to do with gender and the family, including such things as marriage law, women's modesty, and the education of children, are among the most prominent topics in the sermons, occurring in about 20-25 percent of titles and still more often in passing in other sermons. Besides the salience of gendered topics in the recordings, the focus on them is also my own since the strength of feeling on gender roles and the predominance of views that, in a Western context, would readily be described as deeply socially conservative raised my interest.

It will be clear to the reader that while the sermons deserve close attention as texts, they are also deeply context bound. Tracing these contexts is challenging since Muslim reformists in East Africa tend to view any outside interest with mistrust, and a European's doubly so. I relied on three Tanzanian Muslim research assistants to perform background interviews with preachers, producers, listeners, and distributors of sermons. ${ }^{1}$ Since even these relatively familiar outsiders found it difficult to operate in the context of public events, I have not myself attended mihadhara, relying instead on my research assistants' impressions and close examination of the visual information provided by video recordings. While leaving formal interviews largely to fellow Muslims, I have had numerous conversations about the sermons with purveyors, listeners, and indifferent observers, as well as with my research assistants. It should be noted that even without these problems of access, any account of how the sermons are heard can only trace out some patterns amid endless individual variations.

Besides challenging the view of masculinity in Africa as a problem of the young, I use this material to explore three issues in particular. First, the sermons show concern about men's roles, above all in the family, as an important aspect of the much-discussed sense of alienation of East African Muslims within the region's postcolonial states (Kresse 2007; Becker 2008; Burgess 2009; Loimeier 2007). Placing the sermons in this context, I seek to show how they elaborate this sense of crisis, but also that their concerns with masculinity cannot be reduced to political discontent. While at times they target the secular gender-equality agendas of the Tanzanian state and aid agencies, they also examine critically long-standing social practices hitherto considered acceptably Muslim, such as the collective negotiation of bride-wealth (mahari).

Second, the sermons characterise ideal domestic manhood in terms very close to classical definitions of patriarchy (Weber 1947). That is, they focus on men as heads of and providers for families composed of descendants and 
dependents, as 'father-rulers' in the original sense of the term 'patriarch'. They also identify reproduction, fatherhood, as a central pillar and problem of such families. I seek to understand to what extent these claims constitute a challenge to established gender norms in East Africa, in particular in Zanzibar. Moreover, the emphasis on patriarchy contrasts with much recent writing on gender and masculinity in Europe in which the notion of patriarchy has been used with misgivings (Pollert 1996; Gottfried 1998; for a summary see Bennett 2007). Its defenders, meanwhile, have tended to de-emphasise the role of biological reproduction in maintaining it (Walby 1989; Bennett 2007); I will seek to draw out the ways in which the sermons speak to these claims.

Lastly, my reading of the sermons also suggests an understanding of their public role that is at variance with Hirschkind's paradigmatic interpretation of cassette sermon consumption in Egypt as 'ethical listening' (Hirschkind 2006). Hirschkind posits that different preachers and listeners are united by their orientation toward a (culturally specifically 'Islamic') way of listening, focused on the opening up of the listener's heart. It is said to produce certain emotional responses, including tears, and contribute to the development of a kind of reformist subjectivity. All of this ultimately contributes to the development of the 'Islamic counter-public' that Hirschkind argues the sermons and their listeners help constitute. By contrast, as will be seen, the sermons examined here target different audiences separately (of those examined closely two were delivered to men, one to women), express as well as enjoin arguably quitediverse kinds of subjectivities, and (inasmuch as can be ascertained) appear to provoke very diverse responses. I return to the implications of these points in the conclusions.

\section{Islamic Preaching in East Africa in Regional and Global Contexts}

As in other Muslim societies, Friday sermons (hotuba in Swahili), delivered at the mosque after the main Friday prayer, are a long-standing institution among Muslims in East Africa. Loudspeaker equipment was used to broadcast such sermons on special occasions such as Eid since the late colonial period. Also since the middle of the last century, some sermons began to be broadcast by radio (Kresse 2007). Since the 1980 s a new form of media practice has gradually established itself around sermons in the context of a broader movement of Muslim reform and innovation in media use that gained momentum in East Africa relatively late compared to many Muslim-majority countries, becoming widespread only in the 1990s (Roy 1994; Meyer and Moors 2005; Becker 2008). 
This media practice consists in a trade in recorded sermons for consumption at home or in semi-public spaces such as artisans' workshops. Initially on cassette tape but now mostly on DVD, market stalls and shops trading in sermons have become a regular but not particularly conspicuous feature of East African cityscapes. Over the last half-decade, moreover, an increasing share of the offerings of these shops is also reproduced on YouTube, and a profusion of WhatsApp and similar groups facilitates the circulation of snippets of sermons. Surveying the offerings of the stalls, it is clear that at any point in time there are a handful of preachers that are particularly fashionable, with some declining and some rising in popularity.

Of the three preachers considered in detail below, Nassor Bachu was a pioneer of the practice of sermon recording since the 1980 os but his recordings have become less prominent since his death in the early 200os. He is nevertheless widely remembered and respected as an outstanding scholar. Othman Maalim is perhaps the most consistently popular among the core group of preachers, judging by the ubiquity of his sermons. Purveyors and listeners tend to specify his pleasant delivery and his use of engaging kissa, stories, as the reasons why he has endured despite some damaging rumours around 2012/13, about which more below. Hassan Hussein Nyundo appears to have gained popularity fairly rapidly since about 2012, but remains relatively limited in influence to Zanzibar. A self-made preacher who would not be recognised as a learned man by many others in the field, he has polarised opinions with his fierce criticism of women's mores. ${ }^{2}$ All three are Zanzibar-based, but their sermons are sold alongside the products of preachers based in Mombasa, Dar es Salaam, Nairobi, Tabora, and other towns in the region, and occasionally also of diasporic performers (e.g., from Coventry).

The audiences of these traded sermons are by nature difficult to trace. Video recordings give us glimpses of the people present at the actual gatherings, and show a great diversity of by and large 'ordinary' people. However, the recordings have a greater reach. Because sellers were concerned that my asking personal questions of customers might drive away trade I refrained from the attempt to compile a detailed record of buyers, relying instead on an inexact askingaround snowballing approach to find people willing to be interviewed about their sermon listening. One thing that emerges clearly from this sample is that it includes people with very little formal education and precarious livelihoods, who conceive of sermon listening as a way of improving their education.

The preachers meanwhile conceive of themselves and are perceived as proponents of religious reform. As elsewhere in Muslim-majority countries, this reformist movement owes significant intellectual and organizational debts to Middle Eastern countries and especially Saudi Arabia, which began to recruit 
East African students in the 1970s and, with other countries on the peninsula, has supported the building of mosques and community facilities such as healthcare centres (Oded 2000; Becker 2008). Sudan has been another destination for East African reformists. Returnees from such training tend to emphasise the importance of knowledge of Arabic and, following a widespread theme among Wahhabis and Salafists, to criticize non-Quranic bid'a, innovations, in Muslim practice. In this sense, they form part of a global phenomenon.

At the same time, the significance of these sermons arises very much from the way Muslims in East Africa perceive their predicament in its contemporary political context. They live as minorities in religiously diverse societies where educational opportunity, and thus access to the literate administrative and political elite, remained closely tied to missions until the mid-twentieth century, and formal education remains culturally closer to Christian milieus to this day (Kresse 2007). In Kenya, Muslims living in the coastal belt made an abortive bid for unification with the then-sultanate of Zanzibar at the time of independence, fearing domination by the Christian and agricultural centre of the country (Brennan 2008). On the islands of Zanzibar, moreover, the revolution that removed the Omani-dominated sultanate in 1964 resulted in an avowedly socialist government that repressed many Islamic activities for the next thirty years, eroding the islands' tradition of Islamic scholarship (Glassman 2012; Loimeier 2009). In mainland Tanzania as well, Muslims consider themselves educationally and politically disadvantaged (Loimeier 2007).

The broader problem underlying these 'perceptions of marginalisation', in Loimeier's (2007) phrase, is the disenchantment with the paltry gains of independence. While not specific to Muslims, this issue takes on particular significance to them because, in a sense, they gave up more than others to become part of the new nation-states. Zanzibar went through a bloody revolution to shed the British-installed regime, and Muslims in all East African colonies had endorsed the cause of independence early and eagerly (Burgess 2009; Becker 2008). However, the new political language of nationalism left next to no space for articulation of the long-standing cosmopolitan, translocal, Indian-Ocean based identities that coastal and Zanzibari Muslims in particular cherished (Prestholdt 2014; Becker 2014). In recent decades, many of these grievances have found focus in a Zanzibar-centred narrative of Muslim victimhood. In this narrative, the refusal of Tanzania's central government to renegotiate the union between mainland Tanzania (the former Tanganyika) and Zanzibar compounds the injustices done to the islands by the revolutionary government and its neglectful, corrupt, and illegitimate successors (Sheriff 2001). Over the last five years, since Zanzibar's main opposition party (Civic United Front or CUF) that formerly expressed these grievances has joined a unity government, 
a faction of Muslim preachers known as uamsho (awakening) has been at the forefront of demands for Zanzibari independence, resulting in riots, arrests, and police abuses (Matheson 2012).

We will see, though, that there are very few directly political references in the sermons discussed here; rather, the context just outlined forms a background referred to obliquely. The focus of criticism is on the actions of ordinary Muslims, and often on actions that the same Muslims would consider in agreement with their faith. In this sense, the sermons serve as a reminder that Muslim reform in East Africa is not reducible to politics. Yet as I hope to show, in less than obvious ways the preachers do take stances on the region's political divides. With this in mind, I turn next to an issue not of formal but of gender politics: gender asymmetry and hierarchy.

\section{The Foundation of Patriarchy: Male Superiority over Women}

All but one of the sermons on gender relations that I have consulted anchor men's patriarchal authority over women in the former's asserted superior mental, physical, and moral faculties. They do this in part by elaborating the specific flaws of women, and in part by elaborating on gender difference. Overall, these statements amount to a complex mixture of scriptural, legal, sociopolitical, and biological arguments. At times, for instance with regard to the perceived incompatibility of child-rearing with labour market participation, they are hardly different from arguments proffered by conservative Christians in Europe or the United States, or by market liberals opposed to maternity pay. The assertion of male superiority is sufficiently central to these sermons to warrant considering two examples with differing overtones.

First, men's physical and intellectual superiority is discussed at length in a hotuba (Friday sermon) by Abubakary A Kambody, held at Ngazija ('the Comorese') Mosque in central Dar es Salaam. Kambody is a minor preacher; he has not made it onto YouTube and the sermon discussed here is available only on tape. His argument starts with the fact that Eve was created from a rib of Adam's; not, like Adam, entirely formed by God from inanimate matter. She is therefore like a younger sibling of Adam's, and like any younger child she lacks judgment and ability relative to the older (see Stowasser 1994 on this line of reasoning more broadly).

Kambody particularly emphasises that men have better memories than women — due, he says, to their larger hearts, not brains—and that they can therefore hold more things in their minds at once without getting mixed up (a European commentator might say they are better at compartmentalising and multitasking). He illustrates this by elaborating how bad women are at 
cheating on their husbands because they let their emotions show. His arguments, then, are drawn less from the Quran, Islamic law, or hadith than from a particular understanding of biology (the role of the size of the heart) and from everyday experience. He uses domestic examples that resonate with the everyday experience of not necessarily very-religious people, pairing them with the insistence, often found in discussions of gender relations among Muslims, that Islam enhances women's entitlements relative to the pre-Islamic past and serves to protect, not oppress them.

Kambody's reasoning resembles nineteenth-century European discussions of women's 'physiological mental debility', and perhaps also current-day neurophysiologists' assertions of how women's brains are addled by hormones, starting in the womb (Moebius 1900; for a critique of present-day parallels see Fine 2011). However, there is nothing about it that makes it explicitly reformist. Rather, the domestic analogies and the claims about anatomy are kinds of reasoning that could easily also occur in quite-areligious contexts. Although in Kambody's rendering the insertion of these claims in a discourse about religious virtue effectively legitimises them, he does not invoke the textual sources or examples from early Islamic history that mark reformist speakers.

In our second example, Nassor Bachu proffers a more specifically religious reasoning. Overall, Bachu has a much more literate scholarly style. Dying from the aftereffects of a stroke in 2013 at the age of only 55 , he was a leading exponent of mawaidha recording in Zanzibar and a teacher to many of the most influential preachers of today, including the Dar es Salaam-based Nuruddin Kishk and the Zanzibari Ali Msellem, who is currently imprisoned on charges of involvement in riots between police and supporters of the uamsho (religious awakening) movement in Zanzibar (Mzalendo 2015).

Bachu spent almost all his life in Zanzibar, coming to Dar only to seek treatment during his last illness. Relatively light-skinned, portly, with a carefully trimmed beard and a regal bearing, he embodied the dignity that many Zanzibaris, discontented with the islands' present, associate with a better past. He resembled the leading mid-century Sheikh Abdallah Saleh Farsy (who died in 1981) in that he never took a very explicit political stance, but nevertheless through his religious prestige and perceived purism has become a political symbol of sorts, a reference point for explicitly political reformists such as those in uamsho who demand Zanzibar's independence, but deferred to also by politically much more moderate religious leaders for his erudition (Kresse 2007).

His discussion of masculinity and patriarchy occurred in the context of a series of sermons known as Haki za mume na mke, held at a mosque in Zanzibar Town in 2003. ${ }^{3}$ The title translates as 'the rights of husband and wife'. At the end of the first sermon he mentions that they were put on kwa dharura, in 
response to an emergency, suggesting that there had been a recent disturbance in gender relations. This could have been a domestic scandal or some form of political interference, but unfortunately, I have no further information. Bachu discourses sitting behind a table, two books open before him. He speaks calmly and discursively, giving the impression that he meets his audience at eye level. He nevertheless knows how to drive home a point, using modulation of volume and tone, variation and repetition, and combining detailed attention to scripture with kissa, stories of the prophet and his companions, and references to the present. He delivers an enjoyable listening experience, and a credible image of a self-possessed patriarch.

In contrast to Kambody, Bachu explicitly rejects the claim that women were made from a rib of Adam's. He states, 'Hakuna ushahidi', 'there is no proof for this'. Rather, the Prophet likened women to ribs: like them, they are not straight and they cannot be straightened without breaking them. The simile still serves to assert the fundamental difference between men and women: 'Woman is entirely, entirely different from the way a man is. In terms of her build; her gender. People will truly have trouble if they try to put man and woman on the same level. The difference is very great, indeed, truly, truly great'.

In an apparent reference to the Quran verse (4:34) about men being in charge of women, Bachu further asserts that:

to make a woman king or president, here she will fall down, she will end in perdition, she will go under, for the almighty God has built her and given her an overseer to organise her life. It is necessary for a woman to be under [the tutelage of] a person who oversees her life. She cannot do it herself.

NASSOR BACHU

The context that Bachu obliquely addresses here is the official commitment of the Tanzanian state to the pursuit of women's empowerment and gender equality. Most women in Tanzania would probably be surprised to hear how consistent and effective this commitment is according to its critics, not all of them Muslim. While an assessment of the actual reach and effect of this official commitment is beyond the scope of this paper, it is nevertheless clear that despite often narrow practical limits, it is seen as a potential threat to Muslim ways of life. Muslims especially criticise the failure to formalise the use of Islamic law. There is some indication that Tanzania's pluralist legal system offers women some options (Dancer 2015; Stockreiter 2015). Elsewhere in this sermon, he explicates his opposition to initiatives such as the Beijing women's summit of $1997 .{ }^{4}$ Bachu also elaborates further on women's ritual and physical 
weaknesses, closely connecting them to childbearing. Women cannot pray during their periods or after childbirth, and bearing and rearing children also limit their compatibility with the labour market. By describing women as different kijinsia by dint of their gender, he effectively takes a term that was designed to question the fundamental difference between men and women and uses it to reassert precisely this difference.

Finally, Bachu also invokes an apparently widely known story concerning the miraj, the Prophet's miraculous journey around the heavens on the back of a marvelous creature (typically portrayed with a woman's head in East Africa). It is said that Muhammad's followers were startled to hear that he saw many more women than men in the pits of hell. The reason the prophet gave was simple: mnakanusha hatajamii, 'You [women] deny society itself', he said, 'you give a man a child that is not his, to bring up and look after'. With a degree of heat unusual in his diction, Bachu repeats twice that a woman always knows who a child's father is.

This invocation of the miraj and Muhammad's vision of the multitude of women in hell connects Bachu's sermon to another one (examined below) by a speaker known popularly as Shehe Nyundo, 'Sheikh Hammer', and renowned above all for his harsh judgment of women. In all other ways Nyundo is almost Bachu's opposite: educated observers tend to deride him as uneducated and uncouth. ${ }^{5}$ As we see, Nyundo does not invoke false paternity claims as the reason why women outnumber men in hell; he has a much longer explanation. However, Bachu's reference to fears about paternity does make the world he depicts overlap with Nyundo's, where men's legitimate patriarchal control is disintegrating. For Bachu it is not under threat to the same extent but it is very hard work, a matter of sacrifice and self-discipline. I next turn to examining the burdens that patriarchy places on the patriarch, according to Bachu.

\section{The Burdens of the Patriarch, According to Bachu}

Much of Bachu's ninety-minute sermon focuses on two prophetic traditions. One of them, already mentioned, likens women to ribs. However, he spends considerably more time on a hadith in which the prophet implores his followers to not tire in doing good for their women: msieneni kwawafanyia wema wake zenu. In particular, he discusses at length how difficult it is for a man to be evenhanded if he has more than one wife. God himself says so, Bachu asserts:

It is entirely, entirely impossible to be fair between wives. God is speaking to all human beings [when he says this]. You will completely fail to 
treat all wives equally. Truly, even if you are entirely fair in distributing the marital visits, there is no way there could not be a difference in a man's heart; there will be a difference to him between one woman and another ... with regard to all her qualities, the desire she raises, and in the marital act itself the man will experience great differences in his physical reactions and sensations.

NASSOR BACHU

Only God can create love between people, Bachu asserts (implicitly dismissing the use of love potions). Therefore, he also states, having different feelings for different wives is not sinful.

But all the same, men are called on to treat all wives equally. 'If you feed one well one day, feed the other equally another day'; with 'feeding' apparently denoting bringing supplies from the market for the woman in question to cook. The same goes for clothing and every kind of material provision, but also for kind words and attention. In other words, polygamous men have to watch themselves and consciously steer their behaviour so as to minimise the inequalities between wives that their hearts may induce them to practice.

Moreover, men are called on to put up with women, their peculiar ways, their silliness, and their excessive and unwise use of their tongue. Here Bachu returns to the simile of the woman as rib: the rib, the Prophet says, is most crooked at the top-and so is a woman, for her most crooked part is her tongue. If you try to straighten her, you will break her. 'Breaking' a woman in this sense, Bachu asserts, is to divorce her. If you try to correct a woman's speaking habits you will end up in divorce, but divorce is to be avoided wherever possible.

Here Bachu introduces a kissa, a story from early Islamic history about Sayiddna Umar, one of the four 'rightly guided' caliphs that followed the Prophet himself. One day a man went to see Umar with the intention of complaining about his belligerent wife. However, when he reached the caliph's house he stopped, listened, and turned back: he had heard one of the caliph's wives speak to her husband in a manner even sharper than what he had to put up with at home. When Umar asked him why he was not stopping, he explained, 'If the caliph tolerates this kind of behaviour on the part of his wife, I have nothing to complain about'. Patriarchal masculinity, then, is about endurance and forbearance: women will misuse their tongues, and men must put up with it.

According to an obituary published in Mombasa, Bachu had three wives and fifteen children, and so would have encountered the problems he discussed in his own life (Al Huda 2013). His reference to an 'emergency' prompting his delivery of this sermon combined with its emphasis on discord and forbearance 
in a polygynous household makes it seem likely that the sermon was delivered in response to a domestic situation that threatened scandal. Perhaps under different circumstances Bachu might have produced a less-somber depiction of polygynous domesticity and the patriarch's role in it, but he delivered this characterisation with great assurance.

What distinguishes Bachu's patriarchs from unfettered despots is their knowledge that they act under God's watchful eyes and are themselves bound by his commands, and the emphasis on maturity, patience, and self-control. Even under ideal circumstances it is not expected to be an easy role, as is made clear by reference to troubles occurring even in Muhammad's family. Sparing explicit political criticism, his tone and message leave no doubt that in his view Muslims are obliged to disregard all views but the religiously correct one. It is this kind of implicitly political statement that makes him relevant to critics of Zanzibar's current political dispensation.

That said, his message clearly does not exhaust itself in oblique political criticism. Given the emphasis on the patriarch's self-control and domestic discipline, Bachu's sermon resonates with an emphasis on self-reflection and interiority that has been identified as a feature of reformist discourse not only in Tanzania (Roy 2004). However, while Bachu's use of hadith, Arabic-language quotations, and detailed scriptural references also chimes with broader trends among reformists, it should not be overlooked that, as outlined above, he also very much draws on a distinctively Zanzibari precedent. His fluent, elegant Swahili and his self-possessed yet engaged delivery evoke the long-standing ideal of uungwana, the identity of the freeborn patrician (Glassman 1996; Stockreiter 2015).

\section{Patriarchy Undermined? Hassan Hussein Nyundo}

Nassor Bachu's depiction of the patriarch's troubles is very measured compared to that produced by Sheikh Hassan Hussein Nyundo. As I mentioned, Nyundo is a kind of self-taught sheikh, what Roy (1994) might call a 'lumpen-Islamist'. He is said to be a former policeman who turned misogynist preacher because an adored wife left him, or because he failed at a succession of marriages. As will be seen, his sermon is indeed not exactly erudite and at times certainly could be characterised as a misogynist as well as rather self-centred rant. Nevertheless, Nyundo has made a stir on the preachers' scene, and is mentioned as an interesting performer by both men and women with an interest in sermons. He therefore deserves attention. 
His sermon on 'three things women should beware of' was delivered to an audience of women and their young children at a location on the outskirts of Zanzibar Town. The recording shows the sheikh standing in front of a cassava plot, the plants reaching to his head. ${ }^{6}$ With his customary kanzu white robe, Nyundo wears a headscarf wound round his forehead, and a kind of combat vest, a loose khaki garment with numerous pockets. His delivery is emphatic, at times angry, and he appears to be increasingly exhausted toward the end of the ninety-minute performance. Unlike Bachu's video, this recording swerves to the audience at regular intervals. The information this provides is considered below.

Also unlike Bachu, Nyundo puts the story of the predominance of women in hell, observed on the miraj, at the beginning of his sermon. He starts with a long exposition on the constant danger of putting oneself in hell, and the miraj shows that women in particular face this threat. It transpires over the course of his sermons that the three dangers women face are their love of wealth, their love of the world, and their love of their children; all three are liable to lead them to perdition. They do this partly by inducing women to neglect religious duties but, as importantly, by inducing them to undermine men's patriarchal status, especially that of poor men.

Another claim that Nyundo makes about the miraj is that Muhammad found that most people in heaven were wanyonge - approximately downtrodded people and paupers. He repeats this claim several times in the course of the sermon. However, women, Nyundo asserts, do not like paupers; they prefer to indulge their love of wealth and follow well-heeled husbands to hell. Many poor men have been robbed of their wives, and many more have been robbed of their rights. At this point Nyundo uses a phrase that developmental human rights discourse typically applies to women: wamenyimwa haki zao, they have had their rights snatched away (see Dancer 2015 on women's rights activism in Tanzania). He enacts a scene of domestic discord in which the discontented wife tells her downtrodden husband nipishe! (make me cook).

Nyundo's elaboration of the dangers of women's love of wealth and worldly pleasures proceeds in a fairly predictable fashion but with a very informative amount of detail. Women's predilections lead them to reject poor husbands and choose wealthy ones without regard for their religious virtues; they lead these men into adulterous relationships, indecent dressing, and the acceptance of religiously forbidden loans. Women badger husbands for early delivery of cooking ingredients, for clothing and furniture, for mobile phone contracts, and so on. Despite the speaker's condemnation, the exposition of these vices makes engaging listening because of Nyundo's theatrical delivery and the 
wealth of concrete detail he invokes. The theatrical impression of real-life relevance is a likely reason for his ability to reach a female audience.

For instance, he elaborates on the back and forth of marriage negotiations, the mutual visits, the haggling between families over mahari (bridewealth), and the effort to keep secret the sums and goods settled on. He reserves particular ire for what he calls, with real venom, sare, uniforms: the coordinated dresses worn, for instance, by bridesmaids at weddings. He elaborates at length how women insist on sare, how they need new ones constantly, how they are willing to sleep with the tailor to obtain them. Given the connection of sare to much-beloved social functions, the sare can be said to stand for women's self-organised sociability, a strong force in Zanzibari society and, evidently, a source of financial stress and unease over women's independence from husbands (see also Stockreiter 2015). Poverty, Nyundo asserts, is a test set by God, and one that women tend to fail.

Although Nyundo acknowledges that bridewealth is a woman's entitlement under Islamic law, he also quotes a Prophetic saying to the effect that marriages with small bridewealth are blessed. In blank denial of the social realities that he earlier invoked - the negotiation of bridewealth between husband's and wife's families, not individuals - he insists that since mahari is a woman's entitlement it is also her responsibility to 'have compassion' and ensure its reduction in the interest of poor men seeking wives.

Nyundo's primary focus on the struggles of under-resourced husbands leads him to also elaborate on tensions between men. Not only does he deplore richer men 'stealing' poorer men's wives, he also condemns wives' male relatives for taking their side against her husband. His hypothetical example involves a wife calling in her elder brother's support when her husband wants to stop her from going to work and accepting lifts from him. The brother, in turn, is portrayed as deriding the husband for needing financial support from his wife's family. As Nyundo tells his audience, the Quran asserts that amri zote kwa mume, 'all authority [over a woman] lies with the husband'. Inadvertently, then, Nyundo delivers a vivid picture of the complex, multipolar, and negotiable nature of family authority that prevails in Zanzibar instead of the patriarchal ideal he cherishes (Middleton 1994; Stockreiter 2015).

Moreover, Nyundo argues that husbands themselves are failing in their role as moral guardians of their wives by inducing them to dress indecently and offering them worldly pleasures. In a strikingly wistful tone, he describes an areligious husband inducing his wife to put on a little dress with just a fulana (a light piece of cloth) as further cover, saying he will 'lift her to his level [of material sophistication]'. He shows her off on the old town's waterfront where 
people congregate in the early evening, he buys her chicken and chips (Nyundo uses the diminutive vichipsi, attaching a certain daintiness to the dish), perhaps a beer, and they think 'this is how the world should be'. This is a vivid evocation of all that a mnyonge husband may want to give his wife but cannot: a modest but still completely unattainable vision of the good life in presentday Zanzibar. But what will happen when you die? As the wife of such a man, you will die 'without religion' (unakufa huna dini). What then? The answer, of course, is damnation.

The third thing that women love too much, according to Nyundo, is their children. In contrast to Bachu's insistence that women can't pray for a certain period after birth, Nyundo claims that they use their babies as an excuse not to. 'Salehe [the baby] has something strange going on [ana vituko], if I want to pray he cries', is how he paraphrases their claims. In the same vein, women use their children as an excuse to ignore and shut out their husbands. Here Nyundo delivers a carefully observed study of a scene that probably occurs across the world in households with a new baby: the husband coming home expecting attention, the wife jiggling the little one: 'Shhhhh! I'm putting the baby to sleep!' According to him, women sometimes wake up their babies in order to have a reason to ignore their husbands. 'This', he says, 'is the reason homes with children do not have love. Men run away from them'. A woman who tells her husband to be quiet so she can put the baby to sleep, says Nyundo, anakwenda pabaya, is going to a bad place. She should put the child down, saying usinishughulishe, 'Do not keep me busy', and give her husband her full attention. She should likewise put the child in a corner (Nyundo demonstrates this literally) so as to pray. When a husband visits a home of his containing children, they should be told tokeni hapa, baba yenu amekuja, 'Leave here, your father has come'.

This passage is revealing in that it gives a sense of the authority that the family patriarch deserves, in Nyundo's mind. Attention to the patriarch has to be immediate; even the needs of infants should be put aside for him. Nyundo is clearly speaking from experience, but he appears unconcerned that children of the age group that tends to need help to stop crying and sleep could make little sense of a sentence like 'Do not keep me busy'. It is hard to imagine a greater claim to authority in a family setting than to want to override the needs of a crying infant. At the same time, it makes the patriarch himself look oddly needy: like an infant's, his needs can't wait.

Given this highly demanding construal of patriarchal authority, it is perhaps unsurprising that Nyundo considers it under threat. However, the precariousness of patriarchal authority that he deplores is not only due to high expectations; rather, Nyundo's sermon condemning women's covetousness conveys a 
vivid sense of the struggles of economically precarious men trying to become family patriarchs. This issue has well-known precedents in the history of continental East Africa: a thriving household is the first step toward becoming an elder, and the denial of this opportunity to young men in late colonial Kenya has long been considered an important cause of the Mau Mau uprising in 1950s Kenya (Lonsdale 1992; Peterson 2004). However, as our next example shows, these economic struggles do not have to lead aspiring patriarchs to condemn women.

\section{The Romantic Patriarch: Othman Maalim}

A rather sunnier depiction of Islamic domesticity is found in the sermons of Othman Maalim, one of the best-recorded sheikhs in Zanzibar and popular both there and on the mainland. A native of Mombasa, it is said that Maalim was brought to Zanzibar by a mfadili or sponsor, a pious Zanzibari businessman who wanted to make a religious contribution. He therefore operates out of a spacious, custom-built mosque with an attached school. He was apparently quite young when he was given his position, and is still only in early middle age. Over time his position as a religious leader in Zanzibar has been shaped by the polarised politics of the island. Having kept his distance from the uamsho movement, he is perceived as close to the government and called to officiate at the weddings of people affiliated with the ruling party, СсM. Meanwhile, it is widely accepted (though, unsurprisingly, there is no 'hard' evidence) that in 2012 amefumaniwa na mwanamke; he was caught in a compromising position with a woman. While some people say that this has reduced his standing his work continues, and in interviews conducted in 2014 respondents from the islands still named him as a sheikh they liked to listen to.

Maalim delivered his sermon on 'excellent wives and excellent husbands' in Ramadhan, on 8 August 2011. ${ }^{7}$ During the sermon he refers to the fact that many marriages had occurred recently, implying that he is providing advice to the new husbands. His tone is conversational; unlike Bachu, he includes a number of jokes. The audience is all male, mixed in age and, as far as can be established from appearances, probably also in socioeconomic condition. The sermon is not dissimilar to Bachu's in its structure in that it is built around a hadith. However, it dwells less than most on women's faults and is silent on the complications of polygamy. Instead, Maalim focuses on the sorts of positive effort a husband can and should make to have a blissful marriage.

That said, he does not fail to admonish against some feminine misdemeanours. First, there is that of betraying domestic secrets. The hadith he sets out 
with was transmitted by Aisha, the Prophet's favourite wife at the time of his death, and concerns a group of women who were friendly with each other and sat down together to swap stories about how their husbands treated them (see Stowasser 1994 on traditions concerning the Prophet's wives). To this, though, the Prophet said that people giving away the secrets of the home, and especially of the bedroom, was like devils copulating in the street'. Moreover, Maalim mentions Aisha's jealousy with regard to the Prophet's first wife, Khadija. Aisha went so far as to claim that Khadija was old, ugly, and toothless by the time she met the Prophet. The Prophet, says Maalim, defended Khadija but did not get angry at or punish Aisha. As Bachu would also enjoin, he showed forbearance toward her jealousy.

Maalim then considers some of the claims that Aisha's friends made about their husbands. Discussing one who complained about her husband's stinginess, he asserts that the Prophet authorised the wife of one of his companions, whose stinginess was a matter of common knowledge, to augment her spending money with whatever she could find in his coat pockets. He emphasises that 'this is not a green light' (using the English phrase 'green light') 'to steal from each other', but a wife is allowed to help herself to as much money as she honestly needs to provide adequate food and everyday necessities for herself and her children. A husband should not expect his wife to produce the refined kind of food served for breaking the Ramadhan fast on insufficient funds; he should not ask about where 'every single penny' (again, in English) he gave his wife went. Instead, the good husband will offer treats to his wife whenever he can. He should phone her from work to ask after her well-being; he should pick some flowers for her or bring her something from the market, 'even if it is chewing gum'. Too many men are sweetness and light during courtship, borrow cars or money to impress, and turn dour once the marriage is concluded. More than any material provision, though, a good marriage is recognised by the way husband and wife talk to each other; by their faces as they look at each other, and by their whole physical bearing in each other's presence. They should be comfortable with each other, as Aisha and Muhammad were.

Maalim elaborates this importance of emotional closeness with reference to the words of another of Aisha's friends, who boasted how much her husband not only spoilt her with physical adornments and choice food but above all gloried in their togetherness. A wife, asserts Maalim, 'needs happiness and calm'. If she has this she will overcome everything; if she does not, even if you buy her a helicopter (again the English term), she will not be at ease. At this point Maalim refers at length to a television programme about a matchmaker he had recently seen on Al Jazeera. There a wealthy woman who, against the usual pattern, was able to provide for her husband in every way, was found to 
be nevertheless quite unhappy due to his inattention. In other words, even a woman who is not financially and practically dependent on male support will be unhappy without her husband's affection. In a similar vein, another husband who receives praise in Maalim's sermon is the one that his wife likened to a cheetah. Cheetahs, Maalim says, are known to be gentle with their young and shy; he uses the term haya, which for humans is used for the feeling of embarrassment. The point of the comparison, he elaborates, is that this husband is fierce like a lion when outside the home, but amepoa, 'he has cooled down', when he comes home. This gentleness, then, is another quality that the husband in search of excellence should strive to have. In effect, Maalim here asserts the need for husbands to distinguish carefully between public and private behaviour; in a European setting one might say to not take the troubles of the workplace home with them.

Whether by design or not, Maalim does not actually use any of the Swahili terms for 'love' (upendo, mapenzi) in describing the emotional bond of husband and wife. Nevertheless, he comes fairly close to describing a conventional version of married bliss with a husband-provider and a wife-homemaker. It is not impossible that the avoidance of the term 'love' is intentional: the term upendo is widely used in Christian discourse to describe the love of Christians for each other and of God for his creation, while mapenzi can take on sensual overtones. More generally, reformist discourse about domestic rights and responsibilities does not sit comfortably with the proposition of a romantic relationship as the foundation of domesticity, especially since wives are not expected to choose their partners.

Nevertheless, Maalim leaves no doubt regarding the importance of emotional closeness. It is important for the happiness of both partners, but especially the wife. However, it is also important in order to make sure that the husband stays on top of events in his household. As Maalim puts it, if Muhammad had practiced the attitude of many contemporary husbands and said 'What will she [my wife] be able to tell me, she only stirs beans for me' (ananikorogea maharagwe tu), he would never have learned about Aisha's friends' pact to share domestic secrets. That said, contrary to what many men think, Maalim also avows that women can be as smart as them:

We men tend to think because we've been given this maleness [a term he accompanies with a gesture that suggests physical strength], women are not our equals in anything. Not in talk, not in ideas [using the English term]; they can't give you any ideas. But we're wrong, some women have intelligence to beat men.

OTHMAN MAALIM 
The contrasts between Maalim on one hand and both Nyundo and Bachu on the other are evident. Alone among these three preachers, he does not elaborate on women's weakness; rather, he focuses on their needs, and his patriarch is above all a provider. Unlike Nyundo, he does not reflect on the difficulty men may experience in providing material things or the frustrations this may cause. The real test, according to Maalim, is providing for emotional needs. The assertion of authority is marginal to Maalim's description, and the complications of polygyny that dominate Bachu's discussion are not even raised. That said, his insistence that domestic life should be treated secretively puts up barriers for women dealing with abusive partners.

In a sense, Maalim sets the bar lower for Muslim patriarchs than Nyundo: they do not have to achieve the acquiescence of even infants. In another sense, though, he demands more: they are called on to achieve emotional balance, calm, and closeness, a much more ineffable thing. Moreover, in a Zanzibari context, the sermon also illustrates why Maalim passes as a 'government-friendly' sheikh. Quite unlike his colleagues, he avoids indicting official gender-equality stances as ungodly, but like Bachu his depiction of the good patriarch involves a reformist attention to self-reflection and interiority.

\section{Steps Toward an Interpretation: Islamic Reform, Patriarchy, and Muslim Publics}

The preceding pages reported a number of similar-yet-different claims on patriarchal masculinity and gender relations. Interpreting them is challenging: they make clear sense in their own terms, and can be clearly related to specific aspects of the context they arose in. However, from the vantage point of an academic observer reasoning in the categories of interpretive social science, and especially with a feminist sensibility, at first glance they can seem rather flat: yes, they all assert male superiority and dominance in the domestic realm-and? The following pages seek to break down this impression of monotony by returning the sermons to the questions stated above: how do they relate to Islamic reform and its politics more broadly? How do they speak to current academic understandings of patriarchy? How do they relate to current academic interpretations of sermon recordings in Muslim societies?

The first of these questions can be rephrased as: do the sermons reflect a fundamental ideological uniformity in present-day Islamism in its insistence on women's dependence and inferiority, and concomitant rejection of the pursuit of gender equality? At first glance the answer is yes. The sermons are 
unified, fundamentally, by their rejection of any notion of formal, legal, or substantial equality between men and women. In terms of the sort of society that they seek to establish, there appears little to choose between them, yet there are very different kinds of arguments (scriptural, historical, biological/ pseudo-scientific, from everyday experience) and very different styles of argumentation at work. The speakers themselves project quite diverse kinds of masculinity, from Nyundo's street-fighting intensity to Bachu's calm composure.

They also elaborate quite different visions of the ideal patriarch, insistence on gender asymmetry notwithstanding. For Bachu, patriarchal masculinity is a domestic and spiritual discipline exerted under the eyes of God. It is a religiously founded romantic pursuit in Maalim's portrayal, and in Nyundo's it is an entitlement to demand self-discipline of women and children. Besides endorsing patriarchy, what they do have in common is that this patriarchy is always an elusive, not at all assured thing, something that is under threat from religious laxity and a variety of pernicious societal influences ranging from human rights discourses to sexual temptation. It has to be actively pursued and constructed - whether through presents of flowers, through consciously practiced fairness, or through barking orders at children.

Yet which of these threats is the most prominent and how they are to be countered is, again, very much a matter of opinion among the speakers. Nyundo enjoins women's repentance, Bachu their education and toleration; Maalim focuses rather on men's self-reform. Ultimately, then, whether the unifying or the diverse aspects of the sermons come to the fore is a question of the vantage point the observer takes. Approached with a Western outsider's mind-set, above all, with the premise of equality between men and women as a positive value in mind, the somewhat dreary elaboration of male dominance appears as the most salient aspect. However, if we accept this premise of male dominance as a given, then the question of how to assert and practice it finds a myriad of at times quite divergent answers in the sermons.

The diversity of interpretations that underlies the evident uniformity of gender asymmetry in these sermons increases further if we consider the question of how they are heard by their audiences. Answers to this question have to be incomplete since there are as many responses as listeners and an extensive treatment of the question is beyond the scope of this paper, but some patterns can be traced. First, while Nassor Bachu is well represented online, he appears to be more of a preachers' preacher: he is relatively rarely mentioned by sermon listeners when asked who they listen to or who they particularly like. ${ }^{8}$ By contrast, both Othman Maalim and Hassan Nyundo clearly have a popular following. 
Interview respondents rarely dwelled at length on the reasons why they liked particular speakers, but the reasons they did give were fairly similar for Maalim and Nyundo: essentially, they are relatable. ${ }^{9}$ Women who liked Nyundo asserted that he spoke 'about their lives', about issues that they recognised. From a gender equality vantage point, this appreciation for Nyundo is perhaps sobering, but further considerations can be made that raise the possibility that the women's responses are more complex than wholesale acceptance of patriarchal authority. Arguably, Nyundo's dire assessment of women's many tendencies to go astray has the advantage of setting the bar very low: it does not take much for an individual woman to be better, at least in places, than the caricature of women that Nyundo depicts. In a roundabout way, this may offer reassurance to his audience, which is bound to contain many women who reflect consciously on their own religious virtue.

A more-complex point concerns the possibility that women may accept Nyundo's criticism quite sincerely, but nevertheless find themselves justified in failing to correct their behaviour in all the ways he indicates because they accept their own fallibility and the many ways in which the forces of this world are ranged against their correct religious observance. To briefly elaborate this point, it is worth dwelling on the female audience's response to Nyundo's berating them for 'loving their children too much'. It may, of course, be partly this listener's projection of her own feelings, but it appeared to me that when Nyundo reached this point (and the camera conveniently performed a long, slow sweep around the audience), there was a subtle relaxation of interest. Audience members seemed to turn toward each other and, ironically, particularly toward the small children some had brought along. Perhaps they felt it particularly important to stop them from making noise, given what Nyundo was saying, or perhaps they were performing a mental move that, in my experience of Tanzanian domestic life, is part of women's repertoire for dealing with the menfolk: they were quietly focusing on the feminine task at hand while letting the men get on with the normative statements..$^{10}$ Any critical comment on men's assertions would be reserved until they were beyond earshot. The subtext of this move can perhaps be paraphrased as: 'You [my husband, Sheikh, brother...] may well be right in principle, but what if life just isn't like that?' The necessities induced by the pragmatics of life may get the better of any kind of prescription, including religious ones.

Notwithstanding the high religious authority that preachers claim, there is no reason to assume that women set their critical faculties aside when listening to a sermon. They may still evaluate a speech claim by claim. Dealing with infants in particular is a deeply gendered activity that women teach each other and of which they expect men to know less. While they may well seek a 
Sheikh's wisdom on questions related to it, they would not be likely to disregard their own knowledge (which, as Nyundo avers, gives high priority to not leaving infants to cry). A situational, selective response of this kind would enable women to combine a sincere endorsement of Nyundo's criticism of their ways with a less explicit, case-by-case distancing of their own judgments from his claims in a way that resembles Simon's (2009) account of how Muslims in Indonesia square their spiritual ambitions with acknowledgment of the limitations under which they operate.

Considering next the question of how the sermons' vision of patriarchy speaks to current academic understandings and evaluations of this concept, it is striking how clearly it appears to hearken back to a 'classical' version of the phenomenon of the kind described as an ideal type by Max Weber (1947). The sermons describe the pater familias as-ideally-the dispenser of all goods within the household and the guarantor of its moral probity. They thereby also describe a very domestic masculinity, albeit partly by contrasting it with the always-avowed public roles of men — as Maalim put it, the patriarch should be a lion abroad, but calm at home.

This contrasts with a long-standing tendency in women's and gender history to identify men with the public rather than the private sphere, and with widespread mistrust toward the concept of patriarchy as a means of analysis among feminists and gender/women's historians (Vickery 1993). The sermons instead remind the observer to look across public/private distinctions: in them the patriarch's authority within and beyond the household are inextricably linked. In Bachu's story, the Caliph's forbearance at home is the flip side of his public power; more implicitly, he spoke with public authority on the complications of polygamy as a man who had practised it. In a sense, the sermons assert the importance of the domestic domain as a starting point for male dominance more widely. For Muslim men in East Africa the reassertion of domestic patriarchy appears as a step toward the reestablishment of public life as it should be.

At the same time, the highly context-bound, specific, and, at close sight, diverse nature of the claims about masculinity and patriarchy made here should easily serve as a safeguard against the reifying, universalising, and dehistoricising effects that critics have ascribed to the concept of patriarchy. Of course, this patriarchy is very much of a particular time and place. It is also clearly based on a number of pillars: not only does it tie women firmly to the domestic sphere, it also enjoins specific practices within that sphere, and carries with it moral as well as legal judgments. In this sense, it resonates with Sylvia Walby's (1998) claim, adopted by Bennett (2007), that in order to avoid rigid, reifying notions of patriarchy we have to recognise it as multifactorial, as made up of many moving parts. 
In one regard, though, the patriarchy of these sermons diverges from the way recent academic defenders of the concept have construed it: unlike the academics, the preachers emphatically recognise biological reproduction, bearing and rearing children, as one of the key battlegrounds for the maintenance of patriarchy. Bachu uses some of his strongest words of condemnation, taken straight from the Prophet's mouth, for women who misattribute paternity. He speaks as a member of a society in which the role of descent as an organising principle is very salient. By lying about paternity women undermine this principle and, he insists, do so knowingly. Men have no real redress, no way to fend off this danger. Similarly, for Nyundo bearing and rearing children provides women with a particularly intractable source of recalcitrant behaviour.

The sermons thus suggest that judgments and practices referring to biological reproduction should not be written off as a site of the reproduction of gender norms more widely, and of domestic patriarchy in particular. Of course, male desire to control female fertility and the impossibility of achieving reliable control has been identified as a driving force behind the organisation of gender relations since they were first made the object of academic inquiry in the mid-nineteenth century (Bachofen 1865; Engels 1902). However, we do not have to return to these grand evolutionary narratives to recognise that, by dint of its particular combination of desirability and difficulty, having and raising children is a realm of life that is liable to be drawn deeply into the struggles for control and acquiescence that animate the reproduction of gender relations at large and domestic patriarchy in particular. This recognition may also help make the preachers discussed above look a little bit less exotic. After all, squaring bearing and rearing children with maintaining a presence in the public sphere and in formal employment remains a constant challenge for women in the West, precisely because here, too, men tend to hold on to certain standards of feminine domesticity and motherliness and tend to find women with children an even less plausible proposition in the workplace than women, tout court.11

Moreover, keeping this issue in mind also helps acknowledge the psychological tensions so evident especially in Nyundo's delivery. John Tosh's (1994) discussion of the history of masculinity in Britain again suggests that in this regard Zanzibari and British men are not worlds apart. While pointing out that it is quite easy to write histories of masculinity without paying much regard to patriarchy at all, he also argues for the recovery of the concept. Above all, he positions it as a means of keeping in the picture both the systematic and practical, and the psychological and ambivalent aspects of male dominance. As he puts it, 'At one and the same time, men pursue practical goals of gender aggrandizement and are guided by unacknowledged fantasies designed to 
defend the [male] psyche. That, it seems to me, is what patriarchy means' $(1994,198)$.

It seems to me that Tosh's statement quite nicely describes the combination that animates the sermons of the active pursuit of control over dependents, with its obvious advantages, with deep-seated anxiety over the elusiveness of this same aim. Tosh connects it to the undeniable importance of women in bringing up children, including sons: men have to repress memories of women's capabilities as they grow up in order to put women in their place. Put differently, so-called dependents are, after all, also the people that a patriarch himself depends on for both biological and social reproduction, and the patriarchs' relationship with them is charged with a complex mix of religious self-assertion and anxiety about its limits.

Finally, to return to the question of the publics and subjectivities that, following Hirschkind (2006), these sermons may be said to (literally) engender: the reader will appreciate that it appears very difficult to attribute to the audiences of the Swahili sermons one characteristic kind of reaction to them. With regard to Nyundo, for example, alongside a number of endorsements, my interviews also contain an explicitly critical consideration by an educated woman from Zanzibar Town who was involved in efforts to counter his outreach into girls' schools. ${ }^{12}$ Even among the audience documented in the sermon recording discussed above, it is evident that reactions to his claims were not uniform. Not everybody laughed at the same time; not everybody participated in the same call-and-response prayer interjections.

This is not to say that there are not many similarities between the way different listeners spoke about the experience and aims of sermon listening. In particular, kuelimika, to gain education, was stated as a near-universal aim. Typically, respondents neither questioned nor expanded on the meaning and value of education; in keeping with both Muslim reformist and official development discourse, they treated its importance as a given. This is one clear indication that these sermons exist in a discursive field that includes many of their listeners, but the existence of this common ground should not be taken as an indication of uniformity in response. On those occasions when respondents elaborated on why they found education important emphases quickly diverged between things such as general societal progress, strengthening of the Muslim community, or personally distinguishing good from bad.

Overall then, both modes of listening and understandings of content varied greatly among audience members. While Hirschkind would, presumably, readily accept that this is the case-really, it could hardly be expected to be otherwise-he nevertheless asserts what could perhaps be called the hegemony of that way of 'ethical listening' that, to his mind, established the Islamic 
counterpublic in Egypt. In part, this is probably due to the different contexts. Egypt is a stronger and more-repressive state than Tanzania's, and in the Muslim Brothers the country has a more-experienced and better-organised Islamist opposition. But it is also a question of setting the sermons and the way audiences take them up in the broader context of audience members' individual life trajectories and projects, and their capacity to live with shortfalls and contradictions, both consciously and unconsciously (Simon 2009).

Moreover, the three performances considered in detail above express three very-different temperaments and life experiences on the part of the speakers. They suggest that these men have themselves come to quite diverse settlements—or are still struggling to find such — with their patriarchal and more broadly masculine roles. Of course, they are all very much counter many things that are officially Tanzanian policy, starting with the country's official commitment to women's empowerment. However, they reflect an uncertain, halting, conflict-ridden collective search for alternatives rather than a solid oppositional block, and leave open the possibility of quite-varied individual solutions.

\section{Conclusion}

Overall, these sermons open revealing views on the travails of patriarchal masculinity in Swahili-speaking Muslim communities. A sense of crisis in both individual and collective lives is apparent, and closely connected to the postcolonial condition. However, the domestic patriarchy proposed here also enjoins virtues of self-reflection and self-control that do not exhaust themselves in political claims making, and invoke widespread movements for self-reform and the construction of new religious subjectivities (Mahmood 2005). Granted, the preachers pursue the assertion of domestic patriarchy as part of a broader project of conservative social reconstruction. In the process, they both challenge the progressive gender norms advocated by international development organisations and, more haltingly, their governments, and partly appropriate the language of these norms.

Yet while the outlines of a shared project for the establishment of restrictive gender norms are clearly traceable, each of the texts, each of the speakers, and their listeners represent individual solutions to the challenges of living in a very-imperfect world. The sermons, then, deliver a strong reminder that masculinity, like everything to do with gender, is something individuals live and wrestle with, make up and muddle through on a daily basis (Butler 1988). 
With the rise of Muslim reformism in East Africa, certainly the discursive scaffolding within which they operate has become much more elaborate and rigid, but it does not therefore preclude greatly varying personal constructions. Like any kind of masculinity, this patriarchal version is contingent, processual, and place specific.

It is evident that the sermons operate at a multiplicity of levels, presenting layers of subtexts that engage with concerns as diverse as political marginalisation, economic precariousness, and the difficulty of ascertaining paternity. Inevitably, their social uses and personal interpretations are diverse; the social barriers to interaction with committed audience members make them even harder to trace. Yet tentative as observations of listeners' responses remain, two points can be made fairly confidently. One is that currently preachers are rarely challenged when presenting socially deeply conservative views of masculinity and gender relations as normatively Muslim, and that it is widely accepted that 'more restrictive' equals 'more Islamic'. Yet it is equally clear when examining the sermon texts that the arguments in favour of these conservative views are never derived simply from a closer, clearer, or otherwise 'better' reading of scripture; they also depend on extrascriptural sources.

The assumption that scripture sanctifies the kind of patriarchy that Bachu and his colleagues enjoin perhaps nevertheless helps to make this condition livable, not only for the dependents but also for the patriarchs. To this observer, it seems that combining insistence on the moral and social importance of the domestic sphere with that on the constant moral fallibility and intellectual limitations of most of its inhabitants puts patriarchs in a rather lonely position at the top of their households. They are answerable for and intimately concerned with the details of the lives of people who, at the same time, Maalim excepted, are portrayed as unrewarding to interact with. It should be noted that this state of affairs is not specific to reformist Muslim lifeworlds. To this observer, Bachu's somber brilliance, in particular, invokes a kind of distant patriarch, burdened and perhaps even diminished by his responsibilities, that has many counterparts in European literature (e.g., Kafka, 2012).

\section{References}

Bachofen, Johann Jakob. 1861. Das Mutterrecht: eine Untersuchung ueber die Gynaikokratie der alten Welt nach ihrer religioesen und rechtlichen Natur. Stuttgart: Krais und Hoffmann. 
Barker, Gary and Christine Ricardo. 2005. 'Young men and the construction of masculinity in Sub-Saharan Africa: implications for HIV/AIDs, conflict, and violence'. Social Development Papers 26 (Conflict Prevention and Reconstruction Series). Washington, DC: World Bank. http://documents.worldbank.org/curated/en/2005/ o6/6022525/young-men-construction-masculinity-sub-saharan-africa-implications -hivaids-conflict-violence.

Becker, Felicitas. 2008. Becoming Muslim in Mainland Tanzania, 1880-2000. Oxford: Oxford University Press.

Becker, Felicitas. 2014. 'Islam and Imperialism in East Africa'. In David Motadel (ed.), Islam and the European Empires. Oxford: Oxford University Press.

Bennett, Judith M. 2007. History Matters: Patriarchy and the Challenge of Feminism. Philadelphia: University of Pennsylvania Press.

Burchardt, Marian. 2009. 'Subjects of Counselling: HIV/AIDS, Religion and the Management of Everyday Life in South Africa'. In Felicitas Becker and Paul Wenzel Geissler (eds.), AIDs and Religious Practice in Africa. Leiden: Brill, 333-358.

Burgess, G. Thomas. 2009. Race, Revolution, and the Struggle for Human Rights in Zanzibar. Athens: Ohio University Press.

Butler, Judith. 1988. 'Performative Acts and Gender Constitution'. Theatre Journal 40, 519-531.

Dancer, Helen. 2015. Women, Land and Justice in Tanzania. Oxford: James Currey.

Engels, Friedrich. 1909. The Origin of the Family, Private Property and the State. Chicago, IL: Charles H. Kerr and Co.

Farsy, Abdallah Salih and Randall L. Pouwels (translator). 1989. The Shafi' ulama of East Africa, ca. 1830-1970: a hagiographic account. Madison, wIs: University of Wisconsin, African Studies Program.

Glassman, Jonathon. 1996. Feasts and Riot: The Contradictory Consciousness of a Swahili Crowd. Oxford: James Currey.

Glassman, Jonathon. 2012. War of Words, War of Stones: Racial Thought and Violence in Colonial Zanzibar. Bloomington: Indiana University Press.

Gottfried, Heidi. 1998. 'Beyond Patriarchy? Theorizing Gender and Class'. Sociology 32, 451-68.

Hirschkind, Charles. 2006. The Ethical Soundscape: Cassette Sermons and an Islamic Counter-Public. New York: Columbia University Press.

Klugman, Jeni, Lucia Hanmer, Sarah Twigg, Tazeen Hasan, Jennifer McCleary-Sills, and Julieth Santamaria. 2014. 'Voice and Agency: Empowering Women and Girls for Shared Prosperity'. Washington, DC:World Bank Group. https://openknowledge .worldbank.org/handle/10986/19036.

Kresse, Kai. 2007. Philosophising in Mombasa. Edinburgh: Edinburgh University Press. 
Lonsdale, John. 1992. 'The moral economy of Mau Mau'. In Bruce Berman and John Lonsdale (eds.), Unhappy valley: Conflict in Kenya and Africa. Book 1: State and Class. Athens, oH: Ohio University Press, London: James Currey, Nairobi: Heinemann, 265-314.

Matheson, A. 2012. 'Maridhiano: Zanzibar's Remarkable Reconciliation and Government of National Unity'. Journal of Eastern African Studies 6, 591-612.

Meyer, Birgit, and Annelies Moors. 2005. Religion, Media and the Public Sphere. Bloomington: Indiana University Press.

Middleton, John. 1993. The World of the Swahili: an African Mercantile Civilization. New Haven, ст: Yale University Press.

Moebius, Paul Julius. 1900. Ueber den Physiologischen Schwachsinn des Weibes. Halle: Paul Marhold.

Mustapha, Muhammad Raufu (ed.). 2014. Sects and social disorder. Oxford: James Currey.

Myers, G.A. 2002. 'Narrative Representations of Revolutionary Zanzibar'. Journal of Historical Geography 26, 429-448.

Oded, Arye. 2000. Islam and Politics in Kenya. Boulder, co: Lynne Rienner.

Peterson, Derek. 2004. Creative Writing: Translation, Bookkeeping and the Work of the Imagination in Colonial Kenya. Portsmouth, $\mathrm{NH}$ : Heinemann.

Pollert, Anna. 1998. 'Gender and Class Revisited, or, the Poverty of Patriarchy'. Sociology 30, 639-659.

Prestholdt, Jeremy. 2014. 'Politics of the Soil: Separatism, Autochthony and Decolonization at Kenya's Coast'. Journal of African History 55, 1-22.

Roy, Olivier. 1994. The Failure of Political Islam. London: I.B. Tauris.

Sheriff, A. 2001. 'Race and Class in the Politics of Zanzibar'. Africa Spectrum 36, 301-318.

Showalter, Elaine. 1991. Sexual Anarchy: Gender and Culture at the Fin de Siecle. New York: Viking.

Simon, Gregory M. 2009. 'The Soul Free of Cares? Islamic Prayer, Subjectivity, and the Contradictions of Moral Selfhood in Minangkabau, Indonesia'. American Ethnologist 36, 258-275.

Stockreiter, Elke. 2015. Islamic Law, Gender and Social Change in Post-Abolition Zanzibar. Cambridge: Cambridge University Press.

Vickery, Amanda. 1993. 'Golden Age to Separate Spheres: A Review of the Categories and Chronology of English Women's History'. Historical Journal 36, 383-414.

Walby, Sylvia. 1989. 'Theorizing Patriarchy'. Sociology 23, 213-234.

Weber, Max. 1947. The Theory of Social and Economic Organisation. New York: Free Press.

Welford, Judith, and Jane Powell. 'A crisis of modern masculinity: Understanding the causes of male suicide'. Report prepared for Campaign against Living 
Miserably (CALM), 2014. Accessible at https://www.thecalmzone.net/2014/11/ masculinity-audit/.

\section{Notes}

This is perhaps a good place to thank these research assistants, Zuhura Mohamed, Ida Hadjivayanis, Abshir Warsame and Yussuf Hamad, for their crucial contribution to this research. Interviews were partly scripted and partly semi-structured. I also want to thank the Gerda Henkel Foundation, which supported the research for this paper through a grant under its special programme on Islam and transnational movements, and the Framework Programme 7 of the EU, which supported it through a Marie Curie grant, number A-2011-303556 RMSEA.

For this polarising effect compare interviews with educated professionals from Zanzibar Town by Ida Hadjivayanis in July 2013 (who strongly rejects his teachings) with the interview with a Pemban market trader by Yussuf Hassan, July 2014 (who strongly endorses Nyundo).

3 As of January 2017, the link is https://www.youtube.com/watch?v=J-76Ng5zWwM.

4 This women's summit was very widely reported in Tanzania and entered popular culture through the expression mwanabeijing, literally 'child of Beijing', to refer to assertive women.

5 I rely here on the views reported by Ida Hadjivayanis, Yussuf Hamad and Abshir Warsame, who conducted interviews in Zanzibar on my behalf in 2012, 2014 and 2016 respectively.

6 As of January 2017, the link is https://www.youtube.com/watch?v=kGOeblAjNkg.

7 As of January 2017, the link is www.youtube.com/watch?v=adbjI3xydYc.

8 This observation is based on results from several dozen interviews conducted in Pemba in summer 2014, by Yussuf Hamad.

9 I am mainly drawing here on the interviews collected by Yussuf Hamad in Pemba in 2014, and on my own conversations during visits in 2003, 2004, 2005, 2012, and 2016.

10 I am drawing on eight months spent living in a Muslim household in Dar es Salaam, and interviews as well as friendly visits in households in Dar es Salaam, Lindi, and a number of country towns and villages in Lindi and Mtwara Regions, especially Ruponda and Rwangwa.

11 As a former member of a Cambridge college that has been admitting women for little more than thirty years, and of a Cambridge faculty where speed of promotion is known to vary by gender, I am writing from experience. I would like to express my appreciation, though, for those members of both institutions who made sure that maternity leave regulations were implemented very smoothly.

Anonymous interview, Zanzibar Town, conducted by Ida Hadjivayanis in July 2012. 